\title{
PROGRAM PENINGKATAN KEMAMPUAN GURU DALAM PEMBELAJARAN BAHASA JAWA DI SD PATEMON 01 DAN SD SEKARAN 01 KECAMATAN GUNUNGPATI KOTA SEMARANG
}

\author{
Joko Sukoyo ${ }^{1}$, Widodo $^{1}$
}

\begin{abstract}
Learning Javanese language has been starting on since a long time, but still there are some problems found in the field. Problems when learning Javanese language that occur in SD Patemon 01 and SD Sekaran 01, District Gunungpati, Semarang are (1) low capacity of the teachers in creating computer-based learning media, (2) lack of language skills of the teachers in using Javanese language variety of manners, and (3) frequent occurrence of errors in the assessment of learning Javanese language. In connection with these conditions, devotee team tried to be facilitators to the problems faced by teachers in SD Patemon 01 and SD Sekaran 01 by conducting science and technology activities for the Community (IbM). IbM program implementation used workshop model with a variety of methods, such as lecturing, demonstrations, direct practice, frequently asked questions and assignments. The results of this $\mathrm{IbM}$ program are capacity building of teachers in making computers-based learning media for Javanese language, improving the competence of teachers in terms of manners of Javanese language skills, and increaseing understanding of Javanese language learning assessment. The increase was indicated from abilities' score of the teachers before and after the lbM program. The ability of teachers in terms of making computer-based instructional media increased significantly, ie $16.9 \%$. Competence of teachers in terms of unggah-ungguh based on Javanese language, especially in speaking skills manners increased $6.3 \%$. The ability of teachers in terms of understanding of the Java language learning assessment increased $9.7 \%$.
\end{abstract}

Keywords: IbM Program, Javanese Language.

JURNAL PENGABDIAN PADA MASYARAKAT

Website: http://ojs.ejournal.id/index.php/ppm

Permalink: http://ojs.ejournal.id/index.php/ppm/article/view/82

How to cite (APA): Sukoyo, J., \& Widodo. (2017). Program peningkatan kemampuan guru dalam pembelajaran bahasa jawa di SD Patemon 01 dan SD Sekaran 01 Kecamatan Gunungpati Kota Semarang. Jurnal Pengabdian Pada Masyarakat, 2(1), 29-40

This is an open access article distributed under the terms of the Creative Commons Attribution 4.0 International License, which permits unrestricted use, distribution, and reproduction in any medium, provided the original work is properly cited.

\section{PENDAHULUAN}

Sekolah Dasar Patemon 01 dan Sekolah Dasar Sekaran 01 adalah dua SD yang termasuk dalam wilayah Kecamatan Gunungpati, Kota Semarang. Kecamatan Gunungpati terbagi menjadi 16 Kelurahan dengan luas wilayah 5.399.085 Ha. Jumlah penduduknya mencapai 70.901 jiwa yang terhimpun

\footnotetext{
${ }^{1}$ Fakultas Bahasa dan Seni, Universitas Negeri Semarang.

a email: j_sukoyo@yahoo.com.
} 
dari 89 RW dan 418 RT. Kondisi geografis Kecamatan Gunungpati dengan ketinggian dari permukaan air laut $259 \mathrm{M}$ dan sebagian besar berfungsi sebagai lahan konservasi. Batas wilayah Kecamatan Gunungpati, sebelah barat adalah Kecamatan Mijen dan Kabupaten Kendal, sebelah utara adalah Kecamatan Ngaliyan dan Gajah Mungkur, sebelah timur adalah Kecamatan Banyumanik dan Kabupaten Semarang sedangkan sebelah selatan adalah Kabupaten Semarang (Wikipedia.org).

SD Patemon 01 beralamat di jalan Patemon RT. 02, RW. 01. SD Patemon 01 memiliki kondisi lingkungan yang cukup baik. Tingkat kebersihannya juga cukup baik. Hal ini ditunjukkan dengan tersedianya tempat sampah di setiap kelas. Tingkat kebisingan di SD Patemon 01 tidak terlalu tinggi karena gedung sekolah yang terletak di jalan perkampungan sehingga kendaraan yang melintas tidak terlalu padat. Pengolahan air di sekolah ini juga sudah cukup baik. Kondisi jalan yang menghubungkan antara rumah warga dan sekolah juga sudah baik, berbentuk jalan berpaving namun masih sempit..

Ruang kelas di SD Patemon 01 ukurannya cukup kecil sedangkan muridnya terlalu banyak. Masing-masing ruang kelas terdapat berbagai alat-alat yang menunjang kegiatan belajar mengajar seperti: papan tulis, meja kursi guru, meja kursi murid, almari, hiasan dinding, pajangan karya siswa, portofolio siswa, foto presiden, kalender, pancasila, jadwal pelajaran, jadwal piket, struktur organisasi kelas, tata tertib dan media pembelajaran beberapa mata pelajaran. Berdasarkan pengamatan di dalam kelas, terlihat bahwa media-media pembelajaran yang tersedia mayoritas adalah media pelajaran-pelajaran pokok, seperti bahasa Indonesia, matematika maupun pengetahuan alam, nyaris tidak ada media pembelajaran untuk materi pelajaran muatan lokal, seperti bahasa Jawa.

Informasi yang diperoleh dari kepala sekolah yaitu Teguh Budiwati, S.Pd. mengatakan bahwa media pembelajaran bahasa Jawa memang sangat kurang. Hal ini disebabkan karena sekolah sulit menemukan media-media bahasa Jawa yang dijual di pasaran, sedangkan jika ingin membuat sendiri kemampuan guru-guru dalam merancang dan memproduksi media pembelajaran bahasa Jawa sangat kurang, sehingga ketika mengajar hanya bermodalkan LKS yang belum tentu sesuai dengan materi pembelajarannya.

Masih menurut penuturan Kepala Sekolah SD Patemon 01, bawa guru-guru SD mayoritas adalah lulusan Program Studi Pendidikan Guru SD (PGSD) 
bukan Iulusan Program Studi Pendidikan Bahasa dan Sastra Jawa. Kurikulum Program Studi PGSD hanya mengajarkan mata kuliah bahasa Jawa sebanyak 2 SKS. Alokasi waktu mata kuliah Bahasa Jawa yang hanya 2 SKS sangat kurang. Guru-guru merasa kemampuan dalam bahasa Jawa sangat rendah, hal ini berdampak ketika guru mengajar menjadi tidak maksimal.

Masalah pembelajaran bahasa Jawa yang terjadi di SD Patemon 01, juga mirip dengan masalah di SD Sekaran 01 yang terletak di jalan Taman Siswa nomor 10 Sekaran Gunungpati Semarang. SD Sekaran 01 memiliki kondisi lingkungan sekolah yang cukup kondusif untuk dilakukan proses pembelajaran. Tingkat kebersihan sekolah SD Sekaran 01 sudah cukup baik. Hal ini dapat dilihat dari adanya tempat sampah di depan kelas maupun di ruang guru. Terbentuknya regu piket di setiap kelas menandakan SD Sekaran 01 sangat mementingkan kebersihan sekolah baik di luar kelas maupun di dalam kelas.

Secara fisik SD Sekaran 01 cukup representatif untuk pembelajaran, tetapi berkaitan dengan ketersediaan media pembelajaran antar bidang studi ternyata belum merata. Salah satu pelajaran yang belum didukung dengan media pembelajaran yang cukup adalah pelajaran bahasa Jawa. Media pembelajaran yang ada masih bersifat tradisional seperti media gambar huruf Jawa dan beberapa gambar wayang. Padahal SD Sekaran 01 memiliki fasilitas yang cukup lengkap. Guru-guru juga sudah banyak yang memiliki laptop. Laptop tersebut dapat digunakan untuk memproduksi berbagai macam media pelajaran bahasa Jawa yang menarik dan inovatif. Tetapi sayang guru-guru belum mampu membuat media inovatif untuk memaksimalkan pembelajaran bahasa Jawa.

Pelaksanaan kurikulum 2013 mata pelajaran bahasa Jawa sudah berjalan beberapa tahun tetapi keberadaan kurikulum 2013 tersebut belum tersosialaisasi dengan baik. Hal ini tampak pada pemahaman tentang penilaian pembelajaran bahasa Jawa yang masih rendah. Kemampua guru tentang penilaian pembelajaran bahasa Jawa perlu ditingkatkan agar tidak terjadi kesalahan dan menilai siswa. Pelajaran bahasa Jawa memiliki karakter yang khas, sehingga memerlukan pemahaman instrumen penilaian yang khas juga.

Berdasarkan analisis situasi dilapangan dapat ditarik kesimpulan permasalahan yang dihadapi oleh guru-guru SD Patemon 01 dan SD Sekaran 01 adalah sebagai berikut. (1) Rendahanya kemampuan guru dalam membuat media pembelajaran dan minimnya koleksi media 
pembelajaran bahasa Jawa yang tersedia di sekolah, (2) Rendahanya kemampuan dalam hal unggah-ungguh basa Jawa terutama keterampilan berbahasa Jawa ragam krama, dan (3) Rendahnya pemahaman guru tentang penilaian pembelajaran bahasa Jawa.

Berkaitan dengan kondisi tersebut tim pengabdi berupaya untuk menjadi fasilitator terhadap permasalahan yang dihadapi oleh guru-guru di SD Patemon 01 dan Sekaran 01. Mengingat bahasa Jawa adalah salah satu budaya bangsa yang adiluhung dan harus tetap dilestarikan, maka kami, selaku dosen di Program Studi Pendidikan Bahasa dan Sastra Jawa Universitas Negeri Semarang melihat adanya peluang kerjasama dengan para guru, dan dinas pendidikan dalam bentuk program Ipteks bagi Masyarakat (IbM). Dari perspektif Unnes, program IbM ini merupakan pengejawantahan dari tri darma perguruan tinggi, disamping kegiatan pengajaran dan penelitian.

Tujuan dari kegiatan IbM ini adalah sebagai berikut. (1) Meningkatnya pemahaman guru tentang perancangan, produksi, penggunaan media pembelajaran bahasa Jawa di sekolah, (2) Meningkatnya keterampilan berbicara bahasa Jawa ragam krama, terutama pada guru-guru muda, dan (3) Meningkatnya pemahaman guru tentang penilaian pembelajaran bahasa Jawa yang benar.

\section{METODE PELAKSANAAN}

Kegiatan IbM ini dilaksanakan dalam bentuk workshop, dan diikuti oleh 20 guru sebagai mitra IbM. Mitra IbM terdiri dari guru SD Sekaran 01, dan SD Patemon 01. Materi yang diberikan meliputi: (1) pembuatan media pembelajaran berbasis audio visual dengan memanfaatkan Software Sparcol Video Scribe, (2) Unggah-ungguh basa Jawa dengan penekanan keterampilan berbahasa Jawa krama, dan (3) penilaian pembelajaran bahasa Jawa, diantaranya penilaian produk, penilaian unjuk kerja, penilaian portofolio, penilaian tertulis dan penilaian sikap. Metode yang digunakan oleh tim IbM dalam rangka mengatasi permasalahan yang dihadapi oleh mitra disesuaikan dengan jenis kegiatannya. Rincian metode seperti dicantumkan pada Tabel 1.

Guna menilai keberhasilan kegiatan IbM maka diadakan evaluasi. Evaluasi dilakukan dengan cara membandingkan hasil sebelum dilakukan program IbM (Pre Test) dan sesudah dilakukan program lbM (Post Test). Evaluasi yang digunakan adalah penilai produk, penilaian perform (unjuk kerja) dan 
penilaian tertulis. Materi pembuatan media pembelajaran menggunakan evaluasi penilain produk dan tertulis, materi unggah-ungguh basa Jawa dalam hal keterampilan berbahasa Jawa menggunaan penilaian perform (unjuk kerja) dan materi jenis-jenis penilaian pembelajaran bahasa Jawa menggunakan tes tertulis.

Tabel 1. Metode Program IbM

\begin{tabular}{lll}
\hline \multicolumn{1}{c}{ Kegiatan } & \multicolumn{1}{c}{ Metode } & Instrumen Evaluasi \\
\hline $\begin{array}{l}\text { Pembuatan media } \\
\text { pembelajaran berbasis } \\
\text { audio visual }\end{array}$ & $\begin{array}{l}\text { Model workshop dengan } \\
\text { metode ceramah, } \\
\text { demonstrasi, tanya jawab } \\
\text { dan praktik langsung. }\end{array}$ & $\begin{array}{l}\text { Penilaian produk } \\
\text { dan tes tertulis }\end{array}$ \\
\hline $\begin{array}{l}\text { Peningkatan kemampuan } \\
\text { berbahasa Jawa ragam } \\
\text { krama }\end{array}$ & $\begin{array}{l}\text { Model workshop dengan } \\
\text { metode ceramah dan praktik } \\
\text { langsung. }\end{array}$ & $\begin{array}{l}\text { Penilaian perform } \\
\text { (unjuk kerja) }\end{array}$ \\
\hline $\begin{array}{l}\text { Peningkatan pemahaman } \\
\text { dalam jenis-jenis } \\
\text { penilaian pembelajaran } \\
\text { bahasa Jawa }\end{array}$ & $\begin{array}{l}\text { Model workshop dengan } \\
\text { metode ceramah, tanya } \\
\text { jawab, praktik langsung dan } \\
\text { penugasan. }\end{array}$ & Tes tertulis \\
\hline
\end{tabular}

\section{HASIL DAN PEMBAHASAN}

Hasil program IbM ini adalah terjadinya peningkatan kemampuan guru dalam hal penguasaan media pembelajaran bahasa Jawa berbasis komputer, keterampilan berbahasa Jawa krama, dan peningkatan pemahaman tentang penilaian pembelajaran bahasa Jawa. Peningkatan tersebut terlihat dari perbedaan kemampuan sebelum (pre test) dilakukan program lbM dan sesudah (post test) dilakukan program lbM.

Tabel 2. Perbedaan Kemampuan Guru Sebelum dan Sesudah Program IbM

\begin{tabular}{lrrr}
\hline \multicolumn{1}{c}{ Materi } & Sebelum & Sesudah & Peningkatan \\
\hline Media pembelajaran bahasa Jawa & 64,95 & 75,95 & $16,9 \%$ \\
\hline Unggah-ungguh basa Jawa & 74,75 & 79,50 & $6,3 \%$ \\
\hline Penilaian pembelajaran bahasa Jawa & 71,50 & 78,50 & $9,7 \%$ \\
\hline
\end{tabular}

Berdasarkan gambar di atas tampak adanya peningkatan kemampuan mitra IbM dalam hal ini adalah guru SD Patemon 01 dan SD Sekaran 01. Kemampuan guru dalam hal media pembelajaran meningkat cukup 
signifikan yaitu 16,9 \%. Kemampuan unggah-ungguh basa Jawa khususnya keterampilan berbahasa Jawa krama meningkat 6,3\%. Kemampuan guru dalam hal pemahaman tentang penilaian pembelajaran bahasa Jawa meningkat $9,7 \%$. Peningkatan ini terjadi selain karena ketepatan dalam memilih metode selama kegiatan workshop juga disebabkan karena pengaruh motivasi mitra lbM yang tinggi. Mereka sangat antusias mengkuti program IbM ini. Mereka mengaku sangat kurang dalam hal kompetensi mengajar bahasa Jawa karena mata kuliah yang mereka dapatkan selama kuliah hanya 4 SKS untuk materi bahasa Jawa. Selain itu, progam IbM yang berkaitan dengan pembelajaran bahasa Jawa masih sangat jarang dan belum sampai pada sekolah mereka.

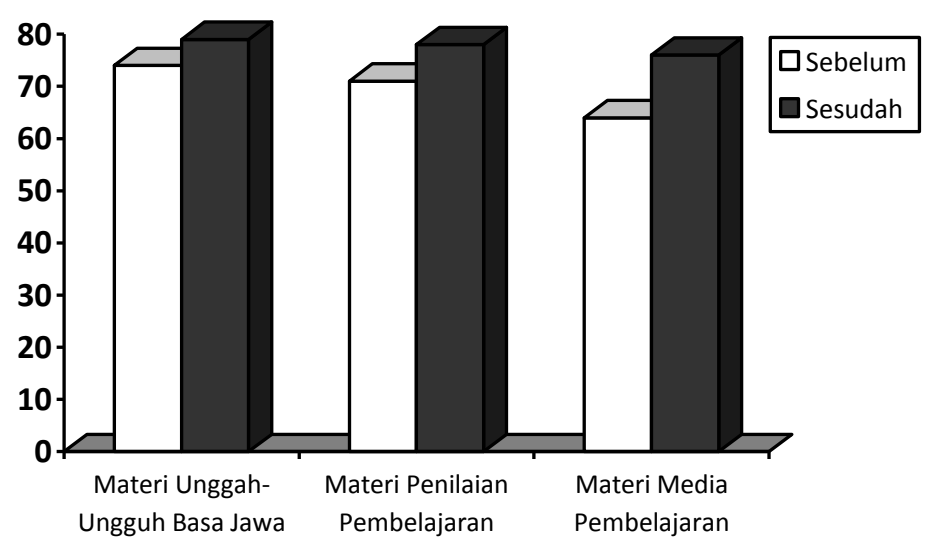

\section{Gambar 1. Bagan Perbedaan Kemampuan Guru Sebelum dan Sesudah Program IbM}

Kegiatan IbM ini dilakukan melalui 8 tahapan, yaitu: 1) Mengurus surat ijin pelaksanaan IbM ke UPTD Dinas Pendidikan Kecamatan Gunungpati Semarang; 2) Sosialisasi program IbM kepada sekolah mitra, yaitu SD Patemon 1 dan SD Sekaran 01; 3) Penyusunan materi-materi program IbM berdasarkan metode pendekatan yang ditawarkan; 4) Pre test untuk mengetahui kemampuan awal; 5) pelaksanakan kegiatan IbM; 6) Post test untuk mengetahui capain hasil; 7) Observasi program IbM; dan 8) Refleksi program IbM.

Tahap pengurusan surat ijin pelaksanaan program IbM dilakukan oleh ketua tim IbM dengan cara menemui langsung kepala sekolah SD Sekaran 01, dan Patemon 01. Ketika proses pengurusan perijinan ini, ketua IbM juga melakukan sosialisasi tentang maksud, tujuan dan manfaat program IbM yang akan dilakukan. Kepala sekolah dari dua SD tersebut sangat antusias 
bahkan berkenan meminjamkan tempat untuk kegiatan IbM. Selain membahas tempat, dibahas juga tentang waktu pelaksanaan program IbM. Waktu dipilih setelah jam mengajar, artinya program ini tidak mengganggu proses kegiatan belajar mengajar. Berdasarkan kesepakatan kepala sekolah dengan tim IbM akhirnya diputuskan pelaksanaan program IbM dilakukan 5 kali pertemuan dengan rincian 1 kali pre test, 3 kali workshop dan 1 kali post test.

Setelah tempat, dan waktu disepakati, kemudian tim lbM menyiapkan materi workshop yang meliputi pembuatan modul unggah-ungguh basa Jawa, pembuatan modul media pembelajaran menggunakan program sparcol video scribe, dan pembuatan modul penilaian pembelajaran bahasa Jawa. Setelah penyusuan materi workshop selesai, kemudian dilakukan pembuatan soal pre test untuk mengetahui kemampuan awal mitra lbM yang berkaitan dengan materi yang akan disampaikan. Pre test dilakukan kepada mitra IbM yang berjumlah 20 guru.

Tahap pelaksanaan program IbM dilakukan tiga kali pelatihan dengan rincian kegiatan berupa: 1) workshop perancangan dan produksi media pembelajaran bahasa Jawa yang inovatif; 2) pelatihan unggah-ungguh basa Jawa khususnya keterampilan berbahasa Jawa karma; dan 3) workshop penilaian pembelajaran bahasa Jawa untuk tingkat SD. Program IbM secara umum berjalan dengan lancar. Peserta mengikuti acara dengan antusias, walaupun ada beberapa guru yang bercerita dengan teman di sampingnya, tetapi hal ini dapat diantisipasi oleh tim lbM.

\section{Workshop Perancangan dan Produksi Media Pembelajaran}

Berdasarkan observasi dan wawancara dengan mitra lbM, mereka mengaku tidak begitu familiar dengan teknologi komputer. Hal ini dikarenakan kebanyakan guru berusia lebih dari 45 tahun. Mereka juga jarang membuat media berbasis komputer. Bahkan ketika mereka mengajar pun hanya menggunakan media seadanya, padahal media memiliki peran yang sangat penting dalam keberhasilan kegiatan belajar mengajar. Seperti pendapatnya Arsyad (2006: 15) bahwa dalam suatu proses belajar mengajar, dua unsur yang amat penting adalah metode mengajar dan media pembelajaran. Kedua aspek ini saling berkaitan. Pemilihan salah satu metode mengajar tertentu akan mempengaruhi jenis media pembelajarannya.

Tim IbM melatih mitra membuat media audio visual dengan memanfaatkan program Sparkol Video Scribe. Video sribe adalah aplikasi yang digunakan 
untuk membuat sebuah video dengan animasi tulis tangan. Gambar tangannya seolah-olah sedang menggambar atau menulis di sebuah papan. Software ini dikembangkan pada tahun 2012 oleh Sparkol, salah satu perusahaan yang ada di Inggris. Aplikasi ini sangat berguna untuk membuat sebuah pengantar pembelajaran dengan animasi yang menarik.

Media pembelajaran yang dibuat mengambil Kompetensi Dasar (KD) Memahami cerita wayang Yudhistira. Kompetensi Dasar ini diajarkan di kelas 4 kurikulum 2013. Materi-materi tersebut disajikan secara singkat, padat dan jelas. Alat bantu yang digunakan adalah LCD proyektor, dengan harapan tampilan layar dapat diterima oleh semua peserta. Tim IbM juga membuat sebuah modul yang berisi langkah-langkah pembuatannya, sehingga guru tinggal membuka modul tersebut jika mengalami kesulitan.

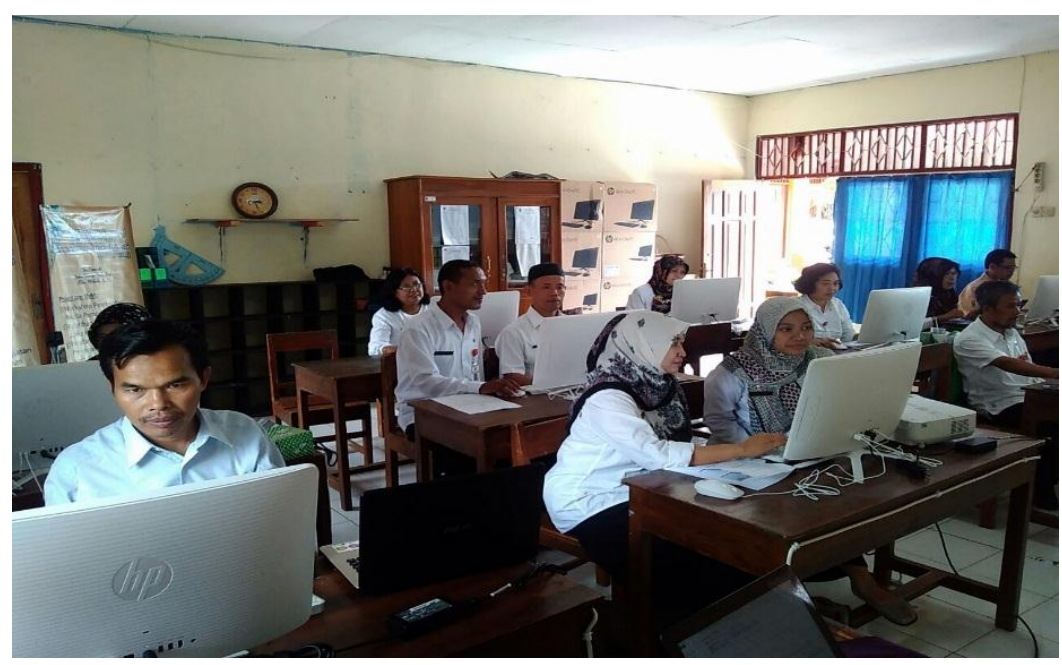

Gambar 2. Mitra IbM sedang membuat media pembelajaran

Mitra IbM mengaku tidak begitu familiar dengan program-program komputer termasuk program sparkol video scribe yang digunakan sebagai program dalam membuat media pembelajaran bahasa Jawa. Lebih dari 50 persen peserta mengalami kesulitan ketika insert gambar atau animasi. Guna mengatasi hal tersebut mitra IbM mendapat pendampingan dari tim IbM dan beberapa tutor dari kalangan mahasiswa yang mumpuni tentang multimedia. Mahasiswa tersebut sengaja diajak untuk membantu mendampingi mitra IbM sekaligus untuk menambah pengalaman dan wawasan mahasiswa.

Guru-guru mitra IbM sangat antusias mengikuti workshop pembuatan media ini. Mereka membutuhkan workshop ini dikarenakan pengetahuan tentang pembuat media pembelajaran berbasis komputer sangat lemah. 
Dengan mengikuti workshop, ilmu yang didapat kelak dapat diterapkan dalam pembelajaran di kelas. Disamping untuk meningkatkan profesionalisme sebagai guru, ternyata mereka juga membutuhkan workshop ini untuk nilai kenaikan pangkat, karena setiap peserta nanti akan diberikan sertifikat oleh tim IbM. Sertifikat ini yang nantinya dapat digunakan oleh para peserta untuk mengajukan pangkat.

Berdasarkan evaluasi pelaksanaan program IbM, terjadi peningkatan yang signifikan dalam hal pembuatan media pembelajaran bahasa Jawa. Skor menunjukkan hasil pre test 64,95 dan hasil post test 75,95, dengan demikian terjadi peningkatan kompetensi sebesar 16, 9\%. Terjadinya peningkatan ini juga didukung faktor motivasi mitra IbM untuk meningkatkan kompetensi dirinya.

\section{Workshop Unggah-Ungguh Basa Jawa}

Guru SD adalah guru kelas, artinya guru tersebut harus mengajar semua materi pelajaran, tidak seperti di SMP atau SMA yang sudah memiliki guru bidang studi. Adanya guru kelas berdampak pada kedalaman materi yang dikuasai oleh guru. Guru SD dituntut untuk menguasai semuan materi pelajaran, termasuk pelajaran bahasa Jawa. Pelajaran bahasa Jawa adalah pelajaran wajib yang harus diajarkan pada tingkat SD sampai SMA sederajat.

Bahasa Jawa merupakan bahasa yang mengenal unggah-unguh basa atau tingkat tutur bahasa. Adanya tingkat tutur ini merupakan adat sopan santun berbahasa. Adat sopan santun ini mencerminkan perilaku kebahasaan yang sebenarnya yang juga tercermin dari perilaku masyarakat. Unggahungguh basa Jawa digolongkan menjadi dua yaitu ragam ngoko dan ragam krama. Ragam ngoko dibagi menjadi dua, yaitu ngoko lugu dan ngoko alus. Sedangkan ragam krama dibagi menjadi dua yaitu krama lugu dan krama alus.

Salah satu kelemahan guru dalam mengajarkan bahasa Jawa adalah tentang kemampuan dalam hal unggah-ungguh basa Jawa, terutama keterampilan berbahasa Jawa krama. Secara umum $100 \%$ guru dapat berbahasa Jawa ngoko, tetapi ketika diadakan pre test untuk mengetahui kemampuan awal terlihat bahwa keterampilan berbahasa krama masih perlu ditingkatkan lagi, terutama pada guru-guru muda. Mereka masih sering menggunakan kosakata krama desa, tembung madya, bahkan ada beberapa guru yang masih salah dalam penggunanan kosakata krama dan krama inggil. 


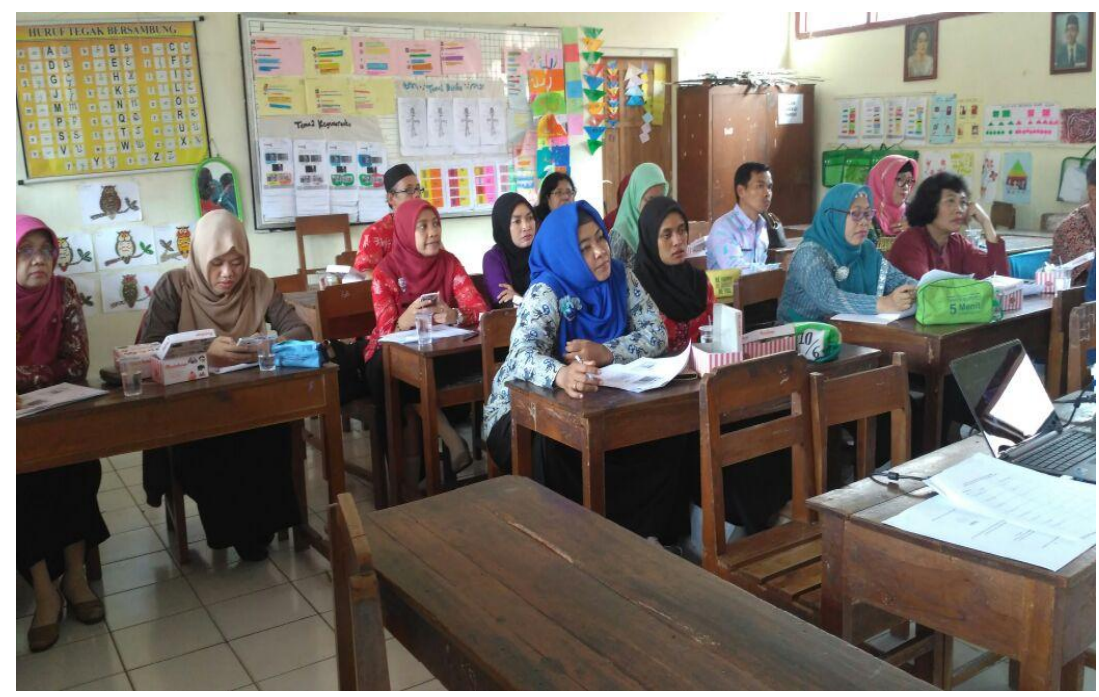

Gambar 3. Mitra IbM sedang mengikuti workshop unggah ungguh basa Jawa

Materi yang dipaparkan dalam workshop diantaranya adalah: (1) sejarah bahasa Jawa, (2) sejarah unggah-ungguh basa Jawa, (3) jenis leksikon dalam bahasa Jawa, dan (4) ragam bahasa Jawa. Konsep program dilaksanakan dengan konsep workshop, artinya tim IbM memberikan teori dilanjutkan praktik. Porsi praktik lebih banyak daripada porsi teori. Berdasarkan hasil penilaian, terjadi peningkatan 6,3\% dalam kemampuan berbahasa Jawa krama. Sebelum dilakukan program IbM rata-rata kompetensi dalam hal keterampilan berbahasa Jawa krama adalah 74,75. Setelah diadakan workshop kompetensnya menjadi 79,5.

\section{Workshop Penilaian Pembelajaran Bahasa Jawa}

Penilaian merupakan suatu kegiatan yang tidak mungkin dipisahkan dari kegiatan pembelajaran secara umum. Semua kegiatan pembelajaran yang dilakukan harus selalu diikuti dengan penilaian. Merupakan suatu hal yang tidak lazim jika terjadi kegiatan pembelajaran yang dilakukan seorang guru di kelas tanpa pernah diikuti oleh adanya suatu penilaian. Tanpa mengadakan penilaian, seorang guru tidak akan mungkin dapat melaporkan hasil pembelajaran peserta didik secara objektif. Selain itu kegiatan penilaian harus dilakukan secara terencana. Kegiatan penilaian yang dilakukan hanya dengan mengandalkan teknik pengamatan saja, jelas kurang dapat dipertanggungjawabkan (Nurgiyantoro, 2011:3)

Mayoritas guru yang mengikuti program IbM, mengadakan penilaian dalam pembelajaran bahasa Jawa dengan menggunakan penilaian tertulis seperti 
pilihan ganda dan uraian, padahal penilaian dalam pembelajaran bahasa Jawa jenisnya bermacam-macam disesuaiakan dengan aspek keterampilan berbahasa yang ingin dicapai. Penilaian pada aspek membaca berbeda dengan penilaian pada aspek berbicara, begitu juga penilaian pada aspek berbicara berbeda dengan penilaian pada aspek menyimak.

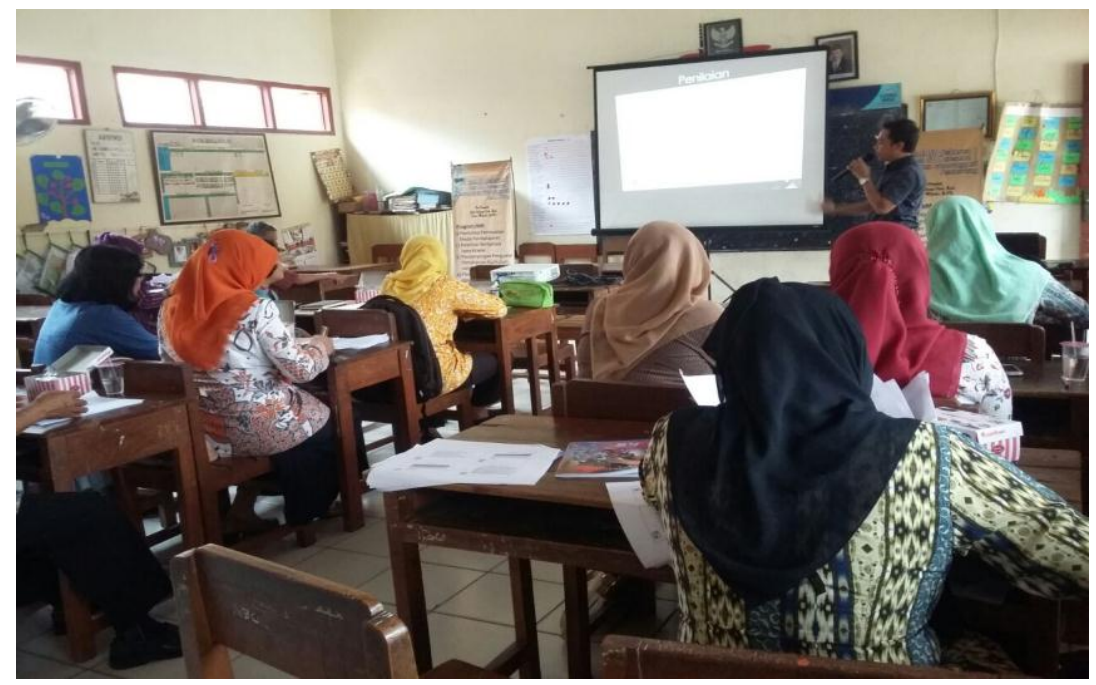

Gambar 4. Mitra IbM sedang mengikuti materi penilaian pembelajaran bahasa Jawa

Materi yang disampaikan dalam worshop ini meliputi jenis penilaian unjuk kerja, penilaian tertulis, penilaian proyek, penilaian produk, penilaian portofolio, penilaian diri dan penilaian sikap. Dengan diberikannya materi jenis-jenis penilaian ini diharapkan mitra lbM dapat menilai kemajuan siswanya. Hal ini senada dengan pendapat Suwandi (2011:18) bahwa tujuan penilaian adalah untuk mengetahui kemajuan hasil belajar siswa, mendiagnosis kesulitan belajar, memberikan umpan balik atau perbaikan proses pembelajaran serta memotivasi belajar peserta didik. Secara umum materi tentang penilaian pembelajaran bahasa Jawa dapat diserap para guru dengan baik dan tidak terdapat kendala yang signifikan. Hal ini terlihat dari peningkatan rata-rata kompetensi guru dari 71,5 menjadi 78,5. Terjadi peningkatan kompetensi sebesar $9,7 \%$.

Selama program IbM berlangsung, tim juga melakukan kegiatan observasi. Kegiatan yang dilakukan selama observasi yaitu mengamati kemudian mencatat kendala-kendala, kekurangan-kekurangan, dan kelemahankelemahan yang muncul dalam kegiatan lbM. Hasil observasi ini merupakan dasar dilakukannya refleksi. Refleksi disini meliputi kegiatan 
analisis, penafsiran dan penyimpulan kegiatan IbM. Hasil refleksi digunakan untuk bahan evaluasi terhadap kegiatan-kegiatan berikutnya.

\section{SIMPULAN}

Berdasakan pelaksanaan program IbM yang sudah dilakukan, maka dapat disimpulkan bahwa: (1) Mitra lbM memiliki minat yang tinggi dalam mengikuti seluruh kegiatan yang disajikan oleh tim lbM, (2) Proses penyampaian materi berupa teori maupun praktik tidak mengalami hambatan yang berarti, sebab penggunaan metode disesuaikan dengan tujuan dan kondisi peserta, artinya peserta dapat langsung praktik dengan bimbingan tim IbM secara intensif. (3) Hasil evalusi menunjukkan bahwa materi yang disampaikan dapat diikuti peserta dengan baik, dan terjadi peningkatan kemampuan yang cukup signifikan. Kemampuan guru dalam hal pembuatan media pembelajaran berbasis komputer meningkat cukup signifikan yaitu 16,9\%. Kemampuan guru dalam hal unggah-ungguh basa Jawa khususnya keterampilan berbicara bahasa Jawa krama meningkat $6,3 \%$. Kemampuan guru dalam hal pemahaman tentang penilaian pembelajaran bahasa Jawa meningkat $9,7 \%$.

\section{REFERENSI}

Arsyad, A. (2011). Media pembelajaran. Jakarta: Raja Grafindo Persada.

Nurgiyantoro, B. (2011). Penilaian pembelajaran bahasa. Yogyakarta: BPEE Yogyakarta.

Suwandi, S. (2011). Model-model asesmen dalam pembelajaran. Surakarta: Yuma Pustaka. 